\title{
Controlling Electrochemical Lithiation/Delithiation Reaction Paths for Long-cycle Life Nanochain-structured $\mathrm{FeS}_{2}$ Electrodes
}

Jie Yang, ${ }^{\mathrm{a}, \mathrm{b}}+$ Meinan Liu, ${ }^{\mathrm{b}+}$ Zhanhua Wei, ${ }^{\mathrm{c}}$ Zhenghui Pan, ${ }^{\mathrm{b}}$ Yongcai Qiu,,${ }^{\mathrm{de}}$ Fangmin Ye,${ }^{\mathrm{b}}$ Yali Yang, ${ }^{a}$ Xinluo Zhao, ${ }^{\mathrm{a}}$ Leimei Sheng, ${ }^{\mathrm{a} a}$ and Yuegang Zhang*b,d

${ }^{a}$ Department of Physics, Institute of Low-Dimensional Carbons and Device Physics, Shanghai University, Shanghai 200444, China.

${ }^{b} i$-Lab, Suzhou Institute of Nano-Tech and Nano-Bionics, Chinese Academy of Sciences, Suzhou 215123, China.

${ }^{c}$ Department of Chemistry, The Hong Kong University of Science and Technology, Clear Water Bay, Kowloon, Hong Kong.

${ }^{\mathrm{d}}$ Department of Physics, Tsinghua University, Beijing 100084, China.

${ }^{e}$ Department of Material Science and Engineering, Stanford University, Stanford, California 94305, United States.

†Jie Yang and Meinan Liu contributed equally to this work.

*CORRESPONDING AUTHOR E-mail: (ygzhang2012@sinano.ac.cn; shenglm@ staff.shu.edu.cn)

Tel. : +86-0512-62872827; Fax : +86-0512-62603079. 


\begin{abstract}
Pyrite $\left(\mathrm{FeS}_{2}\right)$ stands out from other metal sulfides due to its abundance, low toxicity and high specific energy density. However, the low utilization and short cycle life of $\mathrm{FeS}_{2}$ caused by irreversible side reactions and dramatic structural changes during charge/discharge process seriously hinders its practical application. In this work, we designed $\mathrm{FeS}_{2}$ nanochains to address these issues because this unique structure not only shortens the ion/electron diffusion distance, increases the electrode/electrolyte contact area, but also accommodates the strain associated with $\mathrm{Li}$ ion intercalation and deintercalation reactions. Compared with nanoparticles, the $\mathrm{FeS}_{2}$ nanochains synthesized by magnetic-field-assisted aerosol pyrolysis could cycle up to 800 cycles at $0.5 \mathrm{C}$, remained a discharge capacity of $342.4 \mathrm{~mA} \mathrm{~h} \mathrm{~g}^{-1}$ in the voltage range of $1.0-2.6 \mathrm{~V}$ and achieved a remarkable capacity fading rate of $0.02 \%$ per cycle, which is among the best values demonstrated so far for $\mathrm{Li} / \mathrm{FeS}_{2}$ cells. In-situ Raman experiments revealed that the irreversible side reactions could be suppressed through controlling the voltage window, which can be benefit for further improving the performance of $\mathrm{Li} / \mathrm{FeS}_{2}$ cells.
\end{abstract}

Keywords: $\mathrm{FeS}_{2}$ nanochains long-cycle life high capacity in-situ Raman lithium cells 


\section{Introduction}

With the development of mobile devices and electric vehicles, high-energy-density and low cost lithium cells are urgently needed in energy storage device [1]. Pyrite $\left(\mathrm{FeS}_{2}\right)$ has attracted much attention due to its high specific energy density $\left(1273 \mathrm{Wh} \mathrm{kg}^{-1}\right)$ and theoretical capacity (894 $\mathrm{mA} \mathrm{h} \mathrm{g}^{-1}$ ) [2], abundance in natural mineral [3, 4], and low toxicity [5]. Additionally, the capability of overcharge protection enables $\mathrm{FeS}_{2}$ to apply in large type cells [6]. However, the unsolved problems in $\mathrm{FeS}_{2}$ cells, such as active material loss, severe volumetric change, agglomeration of $\mathrm{Fe}^{0}$ nanoparticles, polysulfide dissolution and the subsequent redox shuttle [7, 8], seriously hinders its practical application $[9,10]$.

To address the above challenging issues in $\mathrm{FeS}_{2}$ cathodes, researchers have devoted much effort on the device designs and materials synthesis. For example, Yersak et al. have developed a solid glass-ceramic electrolyte for suppressing the dissolution of polysulfides and agglomeration of $\mathrm{Fe}^{0}$ particles into larger particles [8]. Son et al. have embedded cubic $\mathrm{FeS}_{2}$ into a polyacrylonitrile matrix to confine the electroactive species ( $\mathrm{Fe}^{0}$ and polysulfides) of $\mathrm{FeS}_{2}$ for improving the reversibility and efficiency [9]. Strauss et al. have modified cathode structure for improving the cycling performance by coating a very thin ion-conductive protective film on cathode [11]. However, achieving a high rate and a long cycle life performance for $\mathrm{FeS}_{2}$ cathodes is still difficult. It is widely accepted that the morphology has a great influence on the electrochemical performance of electrode material [12, 13]. With the development of nanotechnology, $\mathrm{FeS}_{2}$ with controllable microstructures, such as wires [14], rods [15], nanoplates [16], cubes [17], and nanocrystals [18], have been achieved. Unfortunately, the best reported performance for $\mathrm{Li} / \mathrm{FeS}_{2}$ cells was about $291 \mathrm{~mA} \mathrm{~h} \mathrm{~g}^{-1}$ after 500 cycles [19], which is far away 
from the commercialization requirement. It is still a challenge to further improve the performance of $\mathrm{Li} / \mathrm{FeS}_{2}$ cells.

Among the controllable morphologies, one dimensional (1D) nanostructures are particularly attractive because their unique geometry not only accelerates the transport rate of electrons, but also creates more active sites for electrochemical reaction, and thus enhances the rate capability $[14,15]$. In addition, the intertwined 1D structure can form a mechanically robust three dimensional (3D) network with porous structure, which can well endure the structural strain upon charging and discharging, and thus prolong the cycle life of electrodes [20]. Herein, we synthesized $\mathrm{FeS}_{2}$ nanochains by magnetic-field-assisted aerosol pyrolysis. The as-prepared intertwined $\mathrm{FeS}_{2}$ nanochain network with numerous nanometer-sized pores exhibits good mechanical properties, which is benefit not only for the rate capability but also for the cycle life. In addition, Raman spectrum as a sophisticated method in understanding the electrochemical reactions has been used in this paper. The results confirm that the control of voltage window is an effective method to reduce the shuttling effect of polysulfides upon cycling. When the voltage window was switched between $2.6 \mathrm{~V}$ and $1.0 \mathrm{~V}$, the $\mathrm{FeS}_{2}$ nanochain cathode could cycle up to 800 cycles and remained the capacity as high as $342.4 \mathrm{~mA} \mathrm{~h} \mathrm{~g}^{-1}$, which is among the longest cycle life demonstrated so far for such a high capacity in $\mathrm{FeS}_{2}$-based lithium cells.

\section{Experimental}

\subsection{Materials}

Iron pentacarbonyl $\left(\mathrm{Fe}(\mathrm{CO})_{5}, 99 \%\right.$, Sigma-Aldrich), Acetone $\left(\mathrm{CH}_{3} \mathrm{COCH}_{3}, 99 \%\right.$, Sinopharm Chemical Reagent Company Limited), SP-type carbon black (TIMCAL, Graphite \&Carbon Ltd), PVDF (polyvinylidene difluoride, Alfa Aesar), NMP (N-methyl-2-pyrrolidone, 
Sigma-Aldrich), MWCNTs (Multi-walled carbon nanotubes, Sigma-Aldrich) were used as received. The electrolyte was $1 \mathrm{M}$ bis (trifluoromethane)-sulfonamide lithium salt (LiTFSI, 99.95\% trace metals basis, Sigma-Aldrich) dissolved in a mixture of 1,3-dioxolane (DOL) and dimethoxymethane (DME) (1:1 by volume).

\section{2 $\mathrm{FeS}_{2}$ nanochains preparation}

As shown in Fig. $1, \mathrm{Fe}(\mathrm{CO})_{5}$ precursor solution $(0.2 \mathrm{M})$ was firstly prepared by mixing 1 $\mathrm{mL}$ of $\mathrm{Fe}(\mathrm{CO})_{5}$ with $35 \mathrm{~mL}$ of acetone, and then the precursor solution was pumped into a homemade ultrasonic atomizer $(1.7 \mathrm{MHz})$. The setup of ultrasonic atomization and pyrolysis process can be found in Fig. S1. It should be noted that this ultrasonic atomization technology can generate very small droplets in range of an extremely narrow diameter compared with conventional pressure nozzles. The atomized aerosol (droplets with a diameter of about $5 \mu \mathrm{m}$ ) was carried by compressed air to a customized glassware, which was heated to $400{ }^{\circ} \mathrm{C}$. As well known, $\mathrm{Fe}(\mathrm{CO})_{5}$ can rapidly decompose into $\mathrm{Fe}$ and $\mathrm{CO}$ at $180{ }^{\circ} \mathrm{C}$ (refer to equation 1) [21]. In this work, the as-prepared Fe nanoparticles could easily react with air and form iron oxide at 400 ${ }^{\circ} \mathrm{C}$ (refer to equation 2). Finally, the $\mathrm{Fe}_{2} \mathrm{O}_{3}$ nanochain network reacted with $\mathrm{H}_{2} \mathrm{~S}$ gas at $300{ }^{\circ} \mathrm{C}$ for 30 min to obtain $\mathrm{FeS}_{2}$ (refer to equation 3).

$$
\begin{aligned}
& \mathrm{Fe}(\mathrm{CO})_{5}=\mathrm{Fe}+5 \mathrm{CO} \quad\left(>180{ }^{\circ} \mathrm{C}\right) \\
& \mathrm{Fe}+\mathrm{O}_{2}=\mathrm{Fe}_{2} \mathrm{O}_{3} \quad\left(>400{ }^{\circ} \mathrm{C}\right) \\
& \mathrm{Fe}_{2} \mathrm{O}_{3}+\mathrm{H}_{2} \mathrm{~S}=\mathrm{FeS}_{2}+\mathrm{H}_{2} \mathrm{O}\left(>300{ }^{\circ} \mathrm{C}\right)
\end{aligned}
$$

\subsection{Electrochemical measurements}


The cathode slurry was prepared by mixing the as-prepared $\mathrm{FeS}_{2}$ materials, SP-type carbon black and PVDF binder with 80:15:5 (by weight) in NMP solution. Then the mixed slurry was spread evenly on an aluminum foil and roll-pressed to form cathode film after heating at $100{ }^{\circ} \mathrm{C}$ for 24 hours under vacuum. The thickness of cathode is around $25 \mu \mathrm{m} .2025$ type coin cells were assembled in an argon filled glove box using lithium foil as the anode.

\subsection{Material characterization}

The microstructure of the as-fabricated $\mathrm{FeS}_{2}$ nanochains were characterized by scanning electron microscopy (SEM, JEOL6700F) and transmission electron microscope (TEM, JEOL 2010). Raman measurement was conducted on a Lab RAM HR evolution Raman spectrometer. X-ray diffraction (XRD) was used to study the crystal structure of the samples with a Bruker D8

diffractometer. Cyclic voltammetry $\left(\mathrm{CV}, 1.0-3.0 \mathrm{~V}, 0.5 \mathrm{mV} \mathrm{s}^{-1}\right)$ measurements were performed on a VMP3 electrochemical working station. Galvanostatic charging/discharging was conducted on land cell program-control test system at rates of 0.05-2 C. X-ray photoelectron spectroscopy (XPS) characterization was performed to investigate information on the surface of $\mathrm{FeS}_{2}$ nanochains on an Axis Ultra DLD XPS. The BET (Brunauere Emmette Teller) specific surface area of the sample was determined by an ASAP 2020 using the standard $\mathrm{N}_{2}$ adsorption and desorption isotherm measurements at $77 \mathrm{~K}$.

$2.5 \mathrm{FeS}_{2}$ prototype cell for in situ Raman experiments

A 2025 type coin cells with a window (Fig. S2) was used to conduct in-situ Raman experiments. It should be noted that MWCNTs (Multi-walled carbon nanotubes) was used as current collector instead of $\mathrm{Al}$ foil for in situ observation. The cathode was prepared by mixing 
MWCNTs and the $\mathrm{FeS}_{2}$ nanochains with a weight ratio of $1: 1$, and then press the mixture into a disc. The following assembly procedure of coin cells is similar as the above.

2.6 $\mathrm{FeS}_{2}$ prototype cell for ex situ XRD spectrum characterization

The electrochemical cells were disassembled after discharging to $2.1 \mathrm{~V}$ and $1.4 \mathrm{~V}$. The structures of the electrode products after lithiation were investigated by powder X-ray diffraction.

\section{Results and Discussion}

As schematically illustrated in Fig. 1, FeS 2 nanochains were synthesized by three steps. Firstly, iron pentacarbonyl precursor from $\mathrm{Fe}(\mathrm{CO})_{5}$ and acetone was decomposed into Fe nanoparticles through an ultrasonic process; then the as-prepared Fe nanoparticles reacted with air to form iron oxide at $400{ }^{\circ} \mathrm{C}$, which was confirmed by XRD results (Fig. 2a). As shown in Fig. 2b, it can be found that the as-formed $\mathrm{Fe}_{2} \mathrm{O}_{3}$ shows porous network structure. TEM images (inset of Fig. 2b), reveal that this porous network is formed by these 1D chains intertwining together and the 1D chains are assembled by nanoparticles with size of 20-30 nm. Considering Fe nanoparticles could be assembled under magnetic-field, therefore, these Fe intermediates formed in equation 1 easily assemble into 1D nanochains with the assistance of magnetic field, and then these Fe nanochains are oxidized by air into $1 \mathrm{D} \mathrm{Fe}_{2} \mathrm{O}_{3}$ nanochains. Finally, the as-formed $\mathrm{Fe}_{2} \mathrm{O}_{3}$ nanochains react with $\mathrm{H}_{2} \mathrm{~S}$ into $\mathrm{FeS}_{2}$ nanochains. SEM and TEM results confirm that the as-obtained $\mathrm{FeS}_{2}$ show 1D nanochain structure with a diameter range of 30-50 nm (Fig. 2c). Furthermore, the results in Fig. $2 \mathrm{~d}$ well reveal that these nanochains are assembled with numerous nanoparticles with the size of 20-30 nm, which is similar to the structure of $\mathrm{Fe}_{2} \mathrm{O}_{3}$ (inset of Fig. 2b). A typical HRTEM image (inset of Fig. 2d) discloses the fine structure of the $\mathrm{FeS}_{2}$ nanochains. The lattice fringes 
with a spacing of $0.3 \mathrm{~nm}$ is consistent with the spacing of the (111) plane of $\mathrm{FeS}_{2}$. Such a nanochain morphology is well preserved even after intense ultrasonic treatment in the TEM sample preparation or casting and roll-pressing step in the cathode preparation (shown in Fig. S3). These results indicate that these nanochains exhibit a good mechanism property, which may endure severe volumetric change of $\mathrm{FeS}_{2}$ during cycling (about 162.2\%, as we computed in Table S1). BET measurement results reveal that the surface area of the as-intertwined $\mathrm{FeS}_{2}$ nanochains is around $37.3 \mathrm{~m}^{2} \mathrm{~g}^{-1}$ (Fig. S4), which is much larger than that of natural cubic $\mathrm{FeS}_{2}$ $\left(0.9431 \mathrm{~m}^{2} \mathrm{~g}^{-1}\right)$ [22]. The total pore volume for this porous network is about $0.1494 \mathrm{~mL} \mathrm{~g}^{-1}$ and the pore size is in the range of 5-40 $\mathrm{nm}$.

The XRD pattern of the as-obtained nanochains cathode was shown in Fig. 3a, and it can be found that all the diffraction peaks match well with the standard pyrite $\mathrm{FeS}_{2}$ peaks (JCPDS Card No. 42-1340). Besides, the crystal structure of nanoparticles was also studied by XRD. As shown in Fig. S5, it can be observed that all diffraction peaks are same for nanochains and nanoparticles, indicating that nanoparticles are also pyrite structure. The structure feature of the as-prepared nanochain was further investigated by Raman analysis. As shown in Fig. 3b, there are three peaks in the Raman spectrum, locating at 339, 376, and $429 \mathrm{~cm}^{-1}$, corresponding to three different characteristic active modes of pyrite $\mathrm{FeS}_{2}, \mathrm{E}_{\mathrm{g}}, \mathrm{A}_{\mathrm{g}}$, and $\mathrm{T}_{\mathrm{g}}$, respectively. The $\mathrm{E}_{\mathrm{g}}$ mode (340-353 $\left.\mathrm{cm}^{-1}\right)$ corresponds to the vibration of $\mathrm{S}$ atoms perpendicular to the dimer axes; whereas the $\mathrm{A}_{\mathrm{g}}$ mode $\left(377-383 \mathrm{~cm}^{-1}\right)$ corresponds to the $\mathrm{S}-\mathrm{S}$ in phase stretching; and the $\mathrm{T}_{\mathrm{g}}$ mode (427-466 $\left.\mathrm{cm}^{-1}\right)$ assigns to mix coupled vibration and stretching mode [23-25]. No obvious vibrational peaks for $\mathrm{Fe}_{\mathrm{x}} \mathrm{S}$ or $\mathrm{Fe}_{\mathrm{x}} \mathrm{O}$ are detected in the range of $200-300 \mathrm{~cm}^{-1}$ [26-29], indicating the high purity of the as-obtained $\mathrm{FeS}_{2}$ nanochains. Moreover, XPS was also used to study the surface information of the as-prepared $\mathrm{FeS}_{2}$ nanochains. As shown in Fig. 3c, the two peaks 
locating at $162.3 \mathrm{eV}$ and $163.5 \mathrm{eV}$ can be attributed to $\mathrm{S} 2 \mathrm{p}_{3 / 2}$ and $\mathrm{S} 2 \mathrm{p}_{1 / 2}$, respectively, which are also consistent with the previous reported sulfur binding energy of pyrite $\mathrm{FeS}_{2}$ [30-33]. In Fe 2p spectrum (Fig. 3d), there are two peaks in Fe 2p core level XPS spectrum, locating at 707.3 and $720.1 \mathrm{eV}$, corresponding to $\mathrm{Fe} 2 \mathrm{p}_{3 / 2}$ and $\mathrm{Fe} 2 \mathrm{p}_{1 / 2}$ binding energies in $\mathrm{FeS}_{2}$, respectively [34], indicating the formation of $\mathrm{Fe}^{2+}$. The peaks locating at $162.3 \mathrm{eV}$ in Fig. $3 \mathrm{c}$ and $707.3 \mathrm{eV}$ in Fig. $3 \mathrm{~d}$ are attributed to pure pyrite $[30,31,35]$. These results again confirm that the as-prepared $\mathrm{FeS}_{2}$ nanochains are of high purity.

To evaluate the superior electrochemical performance of the unique $\mathrm{FeS}_{2}$ nanochains, the Nyquist plots of both $\mathrm{FeS}_{2}$ nanochain and nanoparticle cathodes were obtained by applying a sine wave with amplitude of $5.0 \mathrm{mV}$ over the frequency range from $200 \mathrm{kHz}$ to $0.1 \mathrm{~Hz}$. Compared with nanoparticle-based $\mathrm{FeS}_{2}$ cathode shown in Fig. S6a and Fig. S6b, a smaller semicircle of the nanochain cathode suggests a lower electrochemical resistance. The fitted impedance parameters were listed in Table S2. The SEI film resistance $\mathrm{R}_{\mathrm{f}}$ and charge-transfer resistance $\mathrm{R}_{\mathrm{ct}}$ of the $\mathrm{FeS}_{2}$ nanochain cathode are $67.1 \Omega$ and $105.7 \Omega$, respectively, which are significantly lower than that of the nanoparticle cathode ( $97.8 \Omega$ and $136.1 \Omega$ ). Furthermore, the cells performance based on nanochain cathode and nanoparticle cathode were compared. As shown in Fig. S7, the cell with the nanochain cathode delivers an initial discharge capacity of $598 \mathrm{~mA} \mathrm{~h} \mathrm{~g}^{-1}$, much higher than $498 \mathrm{~mA} \mathrm{~h} \mathrm{~g}^{-1}$ of the cell with nanoparticle cathode. After 100 cycles, the cell could retain the discharge capacity of $355 \mathrm{~mA} \mathrm{~h} \mathrm{~g}^{-1}$ at $0.2 \mathrm{C}$, while the cell with the nanoparticle cathode just delivers around $179 \mathrm{~mA} \mathrm{~h} \mathrm{~g}^{-1}$. The results well demonstrate that morphology has a significant effect on the electrochemical performance. This unique 3D nanochain structure not only benefits for improving the electron transfer kinetics, but also increasing the electrochemical active sites 
with high porosity and large pore size through 1D chains, which thus improves the cell's discharge capacity and cycle stability.

Based on the above results, the electrochemical behavior of nanochain-based cell was carefully investigated. The CV (cyclic voltammetry) of nanochain cathode was conducted in half-cell configuration at room temperature, with a scan rate of $0.05 \mathrm{mV} \mathrm{s}^{-1}$ in the potential range of 1.0-3.0 V (vs Li/Li $\left.{ }^{+}\right)$. As shown in Fig. 4a, there are two main reduction peaks located around 2.1 and $1.4 \mathrm{~V}$ and two oxidation peaks located at $1.8,2.4 \mathrm{~V}$ in the initial discharge/charge cycle. The involved reduction and oxidation reactions are summarized in Table S3 based on the previous reports [7-9]. During the initial discharging process, $\mathrm{FeS}_{2}$ is reduced to $\mathrm{Li}_{2} \mathrm{FeS}_{2}$ at $2.1 \mathrm{~V}$ (equation $\mathrm{S} 1$ ) and further reduced to $\mathrm{Li}_{2} \mathrm{~S}$ and $\mathrm{Fe}^{0}$ at $1.4 \mathrm{~V}$ (equation $\mathrm{S} 2$ ); and then these products can be oxidized to $\mathrm{Li}_{2} \mathrm{FeS}_{2}$ (equation $\mathrm{S} 3$ ), and further to $\mathrm{Li}_{2-x} \mathrm{FeS}_{2}$ (equation $\mathrm{S} 4$ ), $\mathrm{FeS}_{2}, \mathrm{FeS} 8 / 7$ and S (equation S5) $[4,36]$. During $2^{\text {nd }}$ discharging process, it can be found that a new peak located at $2.3 \mathrm{~V}$ appears, which can be attributed to the reduction of $\mathrm{S}$ into high-order $\mathrm{Li}_{2} \mathrm{~S}_{\mathrm{x}}$ (equation S6). At $2.1 \mathrm{~V}$, these high-order $\mathrm{Li}_{2} \mathrm{~S}_{\mathrm{x}}$ can be further reduced to $\mathrm{Li}_{2} \mathrm{~S}$ (equation $\mathrm{S} 7$ ); while $\mathrm{FeS}_{2}$ is reduced to $\mathrm{Li}_{2} \mathrm{FeS}_{2}$ (equation $\mathrm{S} 1$ ). The peak at $1.4 \mathrm{~V}$, can be assigned to the formation of $\mathrm{Li}_{2} \mathrm{~S}$ and $\mathrm{Fe}^{0}$ (equation S2 and S8). Furthermore, the peak area shrinked obviously in the fifth cycle demonstrates the capacity fading of electrode upon cycling, which may be caused by the sidereactions from sulfur into high-order polysulfides.

The control of voltage window has long been proved to be an effective strategy for stabilizing cathode reactions in lithium ion cells, which has also been successfully applied in $\mathrm{FeS}_{2}$ cathodes [37]. In this work, the effect of voltage window range was also investigated. By controlling the voltage in range of 1.0-2.6 V, only two reduction peaks appear at approximately 2.1 and $1.4 \mathrm{~V}$ in the initial discharging process in Fig. 4b, same as the results shown in Fig. 4a, which can also be 
assigned to the transitions from $\mathrm{FeS}_{2}$ to $\mathrm{Li}_{2} \mathrm{FeS}_{2}$ (equation S1) and then to the final discharge products, $\mathrm{Li}_{2} \mathrm{~S}$ and $\mathrm{Fe}^{0}$ (equation $\mathrm{S} 2$ ), respectively. In the oxidation sweep, two peaks located at $1.8 \mathrm{~V}$ and $2.4 \mathrm{~V}$ can be observed. The peak at $1.8 \mathrm{~V}$ can be ascribed to the formation of $\mathrm{Li}_{2} \mathrm{FeS}_{2}$ from $\mathrm{Li}_{2} \mathrm{~S}$ and $\mathrm{Fe}^{0}$ (equation $\mathrm{S} 3$ ). These $\mathrm{Li}_{2} \mathrm{FeS}_{2}$ can be further oxidized to $\mathrm{FeS}_{2}, \mathrm{FeS}$ and $\mathrm{Li}_{2} \mathrm{~S}_{\mathrm{x}}$ at $2.4 \mathrm{~V}$ (equation $\mathrm{S} 9$ and $\mathrm{S} 11$ ). During the $2^{\text {nd }}$ discharging process, there are only two peaks appearing at $2.1 \mathrm{~V}$ and $1.4 \mathrm{~V}$, which are different from the results shown in Fig. 4a (three peaks: $2.3 \mathrm{~V}, 2.1 \mathrm{~V}, 1.4 \mathrm{~V})$. The absent peak at $2.3 \mathrm{~V}$ well suggests almost no polysulfides forming under the window potential of 1.0-2.6 V. The peaks at $2.1 \mathrm{~V}$ can be ascribed to the reduction of $\mathrm{FeS}_{2}$ and $\mathrm{Li}_{2} \mathrm{~S}_{\mathrm{x}}$ described in equation $\mathrm{S} 1$ and $\mathrm{S} 7$. Then these reduction products can be further reduced to $\mathrm{Li}_{2} \mathrm{~S}$ and $\mathrm{Fe}^{0}$ at $1.4 \mathrm{~V}$, as described in equation $\mathrm{S} 2$ and $\mathrm{S} 10$.

The cycle performance comparisons between the cells with the regular voltage window (charging to $3.0 \mathrm{~V}$ ) and the modified recharge setting (charging to $2.6 \mathrm{~V}$ ) are shown in Fig. 4c. Stable electrochemical reactions can be accomplished as long as the voltage window is controlled to $2.6 \mathrm{~V}$, it can deliver an initial discharge capacity of $598 \mathrm{~mA} \mathrm{~h} \mathrm{~g}^{-1}$, remain about $432 \mathrm{~mA} \mathrm{~h} \mathrm{~g}^{-1}\left(0.58 \mathrm{~mA} \mathrm{~h} \mathrm{~cm}^{-2}\right)$ after 450 cycles at $0.2 \mathrm{C}\left(101.6 \mathrm{~mA} \mathrm{~cm}^{-2}\right)$ and preserve stable cycling performance with $0.06 \%$ capacity decay per cycle. However, we found that when the cells were cycled under a regular voltage window (charging to $3.0 \mathrm{~V}$ ), it delivers an initial capacity of $597 \mathrm{~mA} \mathrm{~h} \mathrm{~g}^{-1}$, almost the same value obtained at 1.0-2.6 V $\left(592 \mathrm{~mA} \mathrm{~h} \mathrm{~g}^{-1}\right)$, but the capacity rapidly reduces to $355 \mathrm{~mA} \mathrm{~h} \mathrm{~g}{ }^{-1}$ after 100 cycles, which is much lower than the one operated at 1.0-2.6 V (541.4 $\mathrm{mA} \mathrm{h} \mathrm{g}^{-1}$ after 100 cycles). Correspondingly, the calculated capacity decay per cycle for the cell performed at $1.0-3.0 \mathrm{~V}$ is $2.42 \mathrm{~mA} \mathrm{~h} \mathrm{~g}{ }^{-1}$, much higher than the value of $0.36 \mathrm{~mA} \mathrm{~h} \mathrm{~g}^{-1}$ operated under the voltage range of 1.0-2.6 V. Moreover, the average Coulomb efficiency of the cell operated at $1.0-2.6 \mathrm{~V}$ is much better. To further study the 
efficiency of the voltage window setting, the voltage profile operated at $1.0-2.6 \mathrm{~V}$ and $1.0-3.0 \mathrm{~V}$ were conducted. As shown in Fig. S8a, the initial discharge capacity of the $\mathrm{FeS}_{2}$ nanochain electrode is $592 \mathrm{~mA} \mathrm{~h} \mathrm{~g}^{-1}$ and it keeps at $530 \mathrm{~mA} \mathrm{~h} \mathrm{~g}^{-1}$ for the $3^{\text {rd }}$ cycle with a Coulombic efficiency of $99.8 \%$. In contrast, although the same electrode operated at 1.0-3.0 V exhibits the almost same initial discharge capacity of $596 \mathrm{~mA} \mathrm{~h} \mathrm{~g}^{-1}$, it sharply reduces to $468 \mathrm{~mA} \mathrm{~h} \mathrm{~g}^{-1}$ in the $3^{\text {rd }}$ cycle, as shown in Fig. S8b. These results again reveal that the potential cut-off to $2.6 \mathrm{~V}$ is an efficient way to suppress some side-reactions, can efficiently enhance the capacity of $\mathrm{FeS}_{2}$ nanochain electrode, and thus significantly prolong the cycle life. These results again confirm that the voltage window setting can effectively suppress some side-reactions.

Based on the above results, the voltage window range of 1.0-2.6 V was selected to evaluate the following electrochemical behavior of $\mathrm{FeS}_{2}$ nanochains. As shown in Fig. 4d, at a higher rate of $0.5 \mathrm{C}\left(254 \mathrm{~mA} \mathrm{~cm}^{-2}\right)$, the cell can deliver the highest specific capacity of $466 \mathrm{~mA} \mathrm{~h} \mathrm{~g}^{-1}(0.54$ $\left.\mathrm{mA} \mathrm{h} \mathrm{cm}{ }^{-2}\right)$ at the $60^{\text {th }}$ cycle, and the discharge capacity stabilizes at $421 \mathrm{~mA} \mathrm{~h} \mathrm{~g}^{-1}(0.53 \mathrm{~mA} \mathrm{~h}$ $\left.\mathrm{cm}^{-2}\right)$ after 100 more cycles. The discharge capacity decreases to $380 \mathrm{~mA} \mathrm{~h} \mathrm{~g}{ }^{-1}(0.48 \mathrm{~mA} \mathrm{~h}$ $\left.\mathrm{cm}^{-2}\right)$ after 400 cycles and it can remain at $342.4 \mathrm{~mA} \mathrm{~h} \mathrm{~g}-1\left(0.44 \mathrm{~mA} \mathrm{~h} \mathrm{~cm}{ }^{-2}\right)$ after 800 cycles with a decay rate of $0.02 \%$ per cycle, which is better than the best performance reported so far for $\mathrm{Li} / \mathrm{FeS}_{2}$ cells $(0.1 \%$ per cycle after 500 cycles) [11]. The average Coulomb efficiency of the cell is more than $95 \%$. To further demonstrate the superior performance of our $\mathrm{FeS}_{2}$ nanochain electrode, the specific capacity was also evaluated by the "total" weight (including active materials, super $\mathrm{P}$ additive, and binder). The cells can deliver discharge capacities of $352 \mathrm{~mA} \mathrm{~h}$ $\mathrm{g}_{\text {total }}{ }^{-1}$ after 450 cycles at $0.2 \mathrm{C}$ and $255 \mathrm{~mA} \mathrm{~h} \mathrm{~g}_{\text {total }}{ }^{-1}$ after 800 cycles at $0.5 \mathrm{C}$ based on the total weight, which exhibit a good performance in $\mathrm{FeS}_{2}$-based cells. The advantage of these $\mathrm{FeS}_{2}$ nanochains was further evaluated by the rate performance. As shown in Fig. S9, the discharge 
capacity of electrode at discharge rates of $0.2 \mathrm{C}, 0.5 \mathrm{C}, 1 \mathrm{C}$ and $2 \mathrm{C}$ are 598, 503, 435, and 359 $\mathrm{mA} \mathrm{h} \mathrm{g}{ }^{-1}$, respectively. When the current rate changed back to $0.2 \mathrm{C}$, the discharge capacity recovered to $598 \mathrm{~mA} \mathrm{~h} \mathrm{~g}^{-1}$.

To track the detailed electrochemical reaction processes upon cycling, an in-situ Raman experiment was conducted using a typical coin cell with an observation window as shown in Fig. S2. The fabrication details for this in-situ observation cell can be found in the experimental section. As shown in Fig. 5a, the Raman spectrum recorded at several special voltages upon cycling: (A) at open circuit $2.3 \mathrm{~V}$, (B) initial discharged to $2.1 \mathrm{~V}$, (C) initial discharged to $1.4 \mathrm{~V}$, (D) initial charged to $1.8 \mathrm{~V}$, (E) initial charged to $2.4 \mathrm{~V}$, (F) $2^{\text {nd }}$ discharged to $2.3 \mathrm{~V}$, (G) $2^{\text {nd }}$ discharged to $2.1 \mathrm{~V}$, (H) $2^{\text {nd }}$ discharged to $1.4 \mathrm{~V}$. The corresponding Raman results were shown in Fig. 5(b-d). Table S4 and Table S5 summarized the Raman peaks at different voltages and their corresponding compounds. It can be found that the main compound at stage A was $\mathrm{FeS}_{2}$ [38]. When discharged to $2.1 \mathrm{~V}, \mathrm{Li}_{2} \mathrm{FeS}_{2}$ appeared at stage $\mathrm{B}$, as evidenced by ex-situ XRD patterns (Fig. S10a). The peaks appeared at $14.1^{\circ}, 26.4^{\circ}, 28.8^{\circ}, 42.8^{\circ}, 46.8^{\circ}$, which well matched with the standard peaks of $\mathrm{Li}_{2} \mathrm{FeS}_{2}$ (JCPDS 36-1088). Other peaks located at $28.8^{\circ}$, $37.8^{\circ}, 56.3^{\circ}, 59.0^{\circ}$ can be ascribed to $\mathrm{FeS}_{2}$ (JCPDS 42-1340). When discharged to $1.4 \mathrm{~V}$, the peaks of $\mathrm{Li}_{2} \mathrm{FeS}_{2}$ and $\mathrm{Li}_{2} \mathrm{~S}$ can be observed (Fig. S10b). These results are in good agreement with the Raman measurements and CV results described in the equations S1 and S2 of Table S3 [39, 40]. During charging process (Fig. 5c), it can be found that these $\mathrm{Li}_{2} \mathrm{~S}$ are oxidized to $\mathrm{Li}_{2} \mathrm{FeS}_{2}$ at $1.8 \mathrm{~V}$ (stage D), which is also proved by $\mathrm{CV}$ in Fig. 4b. At stage E, the appearance of $\mathrm{FeS}_{2}, \mathrm{FeS}$ and $\mathrm{Li}_{2} \mathrm{~S}_{\mathrm{x}}$ peaks, and the weaker signal from $\mathrm{Li}_{2} \mathrm{FeS}_{2}$ peaks well indicate the transformation from $\mathrm{Li}_{2} \mathrm{FeS}_{2}$ into $\mathrm{FeS}_{2}$ and $\mathrm{FeS}$. During the $2^{\text {nd }}$ discharging process, it can be concluded that the main compounds are $\mathrm{FeS}_{2}$ and $\mathrm{FeS}$ at $2.3 \mathrm{~V}$, which again confirms the absence of the side-reaction 
from sulfur into polysulfides under voltage window of 1.0-2.6 V. Further discharged to $2.1 \mathrm{~V}$ (stage $\mathrm{G}$ ) and $1.4 \mathrm{~V}$ (stage $\mathrm{H}$ ), the main reduced products are same as initial discharged products. Based on the in-situ Raman results, it can be concluded that the control of voltage window setting strategy is efficient to reduce some side-reactions, especially the one from sulfur into polysulfides. As well known, the polysulfides shuttle effect could cause serious capacity decay upon cycling, the absent of this side-reaction under 1.0-2.6 V may well explain why our cell can achieve a higher capacity and longer cycle life.

\section{Conclusions}

We have successfully synthesized $\mathrm{FeS}_{2}$ nanochains through magnetic-field-assisted aerosol pyrolysis. This 3D $\mathrm{FeS}_{2}$ nanochain network with porous structure exhibits a superior electrochemical performance. It can deliver a specific discharge capacity of $432.3 \mathrm{~mA} \mathrm{~h} \mathrm{~g}^{-1}$ after 500 cycles at $0.2 \mathrm{C}$ and $342.4 \mathrm{~mA} \mathrm{~h} \mathrm{~g}^{-1}$ after 800 cycles at $0.5 \mathrm{C}$, which is among the best performance in the reported results, such as $\mathrm{PAN}-\mathrm{FeS}_{2}\left(470 \mathrm{~mA} \mathrm{~h} \mathrm{~g}{ }^{-1} 50\right.$ cycles) [9], $\mathrm{FeS}_{2} @ \mathrm{C}$ (495 mA h g ${ }^{-1} 50$ cycles) [41] and $\mathrm{Li} / \mathrm{FeS}_{2}$ film cell (291 $\mathrm{mA} \mathrm{h} \mathrm{g}^{-1} 500$ cycles) [19]. Our in-situ Raman experiments demonstrated that this remarkable performance is benefit from the successful suppression the side-reaction from sulfur into long-chain lithium polysulfides through controlling the voltage window. The simple, low cost synthesis approach enables the $\mathrm{FeS}_{2}$ nanochain electrode to be more promising and competitive for the future applications in lithium cells. 


\section{Acknowledgements}

This work was supported by the National Natural Science Foundation of China (Grant no. 51202137, 11544011, 21403287, and 21433013), the National Science Foundation for Postdoctoral Scientists of China (No. 2014M550314, No. 2014M551677), the Natural Science Foundation of Jiangsu Province (BK20140383), and Suzhou Science and Technology Development Program (ZXG2013002).

\section{References}

[1] V. Livshits, A. Blum, E. Strauss, G. Ardel, D. Golodnitsky, E. Peled, Development of a bipolar Li/composite polymer electrolyte/pyrite battery for electric vehicles, J. Power Sources, 97-8 (2001) 782-785.

[2] D.A. Totir, I.T. Bae, Y. Hu, M.R. Antonio, M.A. Stan, D.A. Scherson, In situ Fe K-edge Xray absorption fine structure of a pyrite electrode in a $\mathrm{Li} /$ polyethylene oxide $\left(\mathrm{LiClO}_{4}\right) / \mathrm{FeS}_{2}$ battery environment, J. Phys. Chem. B, 101 (1997) 9751-9756.

[3] Y. Shao-Horn, S. Osmialowski, Q.C. Horn, Reinvestigation of lithium reaction mechanisms in $\mathrm{FeS}_{2}$ pyrite at ambient temperature. J. Electrochem. Soc., 149 (2002) A1547-A1555.

[4] L.A. Montoro, J.M. Rosolen, Gelatin/DMSO: a new approach to enhancing the performance of a pyrite electrode in a lithium battery, Solid State Ionics, 159 (2003) 233-240.

[5] C. Wadia, A.P. Alivisatos, D.M. Kammen, Materials availability expands the opportunity for large-scale photovoltaics deployment. Environ. Sci. Tech., 43 (2009) 2072-2077.

[6] C. Cagli, F. Nardi, B. Harteneck, Z. Tan, Y. Zhang, D. Ielmini, Nanowire switches: resistiveSwitching crossbar memory based on Ni-NiO core-shell nanowires, Small, 7 (2011) 2818-2818. 
[7] T. Evans, D.M. Piper, S.C. Kim, S.S. Han, V. Bhat, K.H. Oh, S.-H. Lee, Ionic liquid enabled $\mathrm{FeS}_{2}$ for high-energy-density lithium-ion batteries, Adv. Mater., 26 (2014) 7386-7392.

[8] T.A. Yersak, H.A. Macpherson, S.C. Kim, V.-D. Le, C.S. Kang, S.-B. Son, Y.-H. Kim, J.E. Trevey, K.H. Oh, C. Stoldt, S.-H. Lee, Solid state enabled reversible four electron storage, Adv. Energy Mater., 3 (2013) 120-127.

[9] S.B. Son, T.A. Yersak, D.M. Piper, S.C. Kim, C.S. Kang, J.S. Cho, S. S. Suh, Y. U. Kim, K.H. Oh, S.H. Lee, A stabilized PAN-FeS 2 cathode with an EC/DEC liquid electrolyte, Adv. Energy Mater., 4 (2014),1300961(1)-1300961(5).

[10] D. Golodnitsky, E. Peled Pyrite as cathode insertion material in rechargeable lithium/composite polymer electrolyte batteries, Electrochim. Acta, 45 (1999) 335-350.

[11] D.G. Strauss E, E. Peled, Cathode modification for improved performance of rechargeable lithium/composite polymer electrolyte-pyrite battery, Electrochem. Solid-State Lett., 2 (1999) 115-117.

[12] Y.J. Mai, J.P. Tu, X.H. Xia, C.D. Gu, X.L. Wang, Co-doped NiO nanoflake arrays toward superior anode materials for lithium ion batteries, J. Power Sources, 196 (2011) 6388-6393.

[13] X.H. Huang, J.P. Tu, X.H. Xia, X.L. Wang, J.Y. Xiang, L. Zhang, Porous NiO/poly(3,4ethylenedioxythiophene) films as anode materials for lithium ion batteries, J. Power Sources, 195 (2010) 1207-1210.

[14] D.R. Cummins, H.B. Russell, J.B. Jasinski, M. Menon, M.K. Sunkara, Iron sulfide (FeS) nanotubes using sulfurization of hematite nanowires, Nano Lett., 13 (2013) 2423-2430.

[15] A. Ennaoui, S. Fiechter, C. Pettenkofer, N. Alonso-Vante, K. Büker, M. Bronold, C. Höpfner, H. Tributsch, Iron disulfide for solar energy conversion, Sol. Energ. Mat. Sol. C., 29 (1993) 289-370. 
[16] M.S. Faber, K. Park, M. Cabán-Acevedo, P.K. Santra, S. Jin, Earth-abundant cobalt pyrite $(\mathrm{CoS} 2)$ thin film on glass as a robust, high-performance counter electrode for quantum dotsensitized solar cells, J. Phys. Chem. Lett., 4 (2013) 1843-1849.

[17] V. Gonzalez-Pedro, X. Xu, I. Mora-Sero, J. Bisquert, Modeling high-efficiency quantum dot sensitized solar cells, ACS Nano, 4 (2010) 5783-5790.

[18] A. Kirkeminde, B.A. Ruzicka, R. Wang, S. Puna, H. Zhao, S. Ren, Synthesis and optoelectronic properties of two-dimensional FeS2 nanoplates, ACS Appl. Mater. Inter., 4 (2012) $1174-1177$.

[19] H. Siyu, L. Xinyu, L. QingYu, C. Jun, Pyrite film synthesized for lithium-ion batteries, J. Alloy. Compd., 472 (2009) L9-L12.

[20] D.K. Kim, P. Muralidharan, H.W. Lee, R. Ruffo, Y. Yang, C.K. Chan, H. Peng, R.A. Huggins, Y. Cui, Spinel $\mathrm{LiMn}_{2} \mathrm{O}_{4}$ nanorods as lithium ion battery cathodes, Nano Lett., 8 (2008) 3948-3952.

[21] Z. Wei, Z. Zhou, M. Yang, C. Lin, Z. Zhao, D. Huang, Z. Chen, J. Gao, Multifunctional $\mathrm{Ag} @ \mathrm{Fe}_{2} \mathrm{O}_{3}$ yolk-shell nanoparticles for simultaneous capture, kill, and removal of pathogen, J. Mater. Chem., 21 (2011) 16344-16348.

[22] L. Liu, Z. Yuan, C. Qiu, J. Liu, A novel $\mathrm{FeS}_{2} / \mathrm{CNT}$ micro-spherical cathode material with enhanced electrochemical characteristics for lithium-ion batteries ,Solid State Ionics, 241 (2013) 25-29.

[23] V. Toniazzo, C. Mustin, J.M. Portal, B. Humbert, R. Benoit, R. Erre, Elemental sulfur at the pyrite surfaces: speciation and quantification, Appl. Surf. Sci., 143 (1999) 229-237.

[24] B. Yuan, W. Luan, S.T. Tu, One-step synthesis of cubic $\mathrm{FeS}_{2}$ and flower-like $\mathrm{FeSe}_{2}$ particles by a solvothermal reduction process, Dalton T., 41 (2012) 772-776. 
[25] A.M. Golsheikh, N.M. Huang, H.N. Lim, C.H. Chia, I. Harrison, M.R. Muhamad, One-pot hydrothermal synthesis and characterization of $\mathrm{FeS}_{2}$ (pyrite)/graphene nanocomposite, Chem. Eng. J., 218 (2013) 276-284.

[26] J.A. Bourdoiseau, M. Jeannin, C. Rémazeilles, R. Sabot, P. Refait, The transformation of mackinawite into greigite studied by Raman spectroscopy, J. Raman Spectrosc., 42 (2011) 496504.

[27] K. Brezesinski, J. Haetge, J. Wang, S. Mascotto, C. Reitz, A. Rein, S.H. Tolbert, J. Perlich, B. Dunn, T. Brezesinski, Ordered mesoporous alpha- $\mathrm{Fe}_{2} \mathrm{O}_{3}$ (hematite) thin-film electrodes for application in high rate rechargeable lithium batteries, Small, 7 (2011) 407-414.

[28] Y. Bi, Y. Yuan, C.L. Exstrom, S.A. Darveau, J. Huang, Air stable, photosensitive, phase pure iron pyrite nanocrystal thin films for photovoltaic application, Nano Lett., 11 (2011) 49534957.

[29] R. Morrish, R. Silverstein, C.A. Wolden, Synthesis of stoichiometric $\mathrm{FeS}_{2}$ through plasmaassisted sulfurization of $\mathrm{Fe}_{2} \mathrm{O}_{3}$ nanorods, J. Am. Chem. Soc., 134 (2012) 17854-17857.

[30] X. Qiu, M. Liu, T. Hayashi, M. Miyauchi, K. Hashimoto, Solution-based synthesis of pyrite films with enhanced photocurrent generation, Chem. Commun., 49 (2013) 1232-1234.

[31] C. Wadia, Y. Wu, S. Gul, S.K. Volkman, J. Guo, A.P. Alivisatos, Surfactant-assisted hydrothermal synthesis of single phase pyrite $\mathrm{FeS}_{2}$ nanocrystals, Chem. Mater., 21 (2009) 25682570.

[32] J. Xu, H. Xue, X. Yang, H. Wei, W. Li, Z. Li, W. Zhang, C.S. Lee, Synthesis of honeycomb-like mesoporous pyrite $\mathrm{FeS}_{2}$ microspheres as efficient counter electrode in quantum dots sensitized solar cells, Small, 10 (2014) 4754-4759. 
[33] C.S. Rout, B.-H. Kim, X. Xu, J. Yang, H.Y. Jeong, D. Odkhuu, N. Park, J. Cho, H.S. Shin, Synthesis and characterization of patronite form of vanadium sulfide on graphitic layer, J. Am. Chem. Soc., 135 (2013) 8720-8725.

[34] J. Xia, X. Lu, W. Gao, J. Jiao, H. Feng, L. Chen, Hydrothermal growth of $\mathrm{Sn}^{4+}$-doped FeS 2 cubes on FTO substrates and its photoelectrochemical properties, Electrochim. Acta, 56 (2011) 6932-6939.

[35] S. Seefeld, M. Limpinsel, Y. Liu, N. Farhi, A. Weber, Y. Zhang, N. Berry, Y.J. Kwon, C.L. Perkins, J.C. Hemminger, R. Wu, M. Law, Iron pyrite thin films synthesized from an Fe(acac)3 ink, J. Am. Chem. Soc., 135 (2013) 4412-4424.

[36] R. Fong, J.R. Dahn, C.H.W. Jones, Electrochemistry of Pyrite-Based Cathodes for AmbientTemperature Lithium Batteries, J. Electrochem. Soc., 136 (1989) 3206-3210.

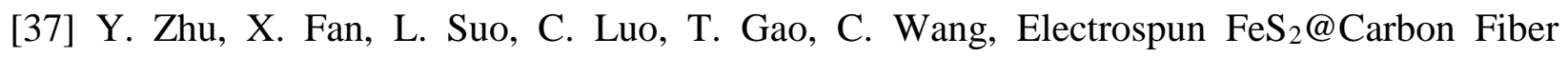
Electrode as a High Energy Density Cathode for Rechargeable Lithium Batteries, ACS Nano, 10 (2016) 1529-1538.

[38] B.X. Yuan, W.L. Luan, S.T. Tu, J. Wu, One-step synthesis of pure pyrite $\mathrm{FeS}_{2}$ with different morphologies in water, New J. Chem., 39 (2015) 3571-3577.

[39] H. Yao, K. Yan, W. Li, G. Zheng, D. Kong, Z.W. Seh, V.K. Narasimhan, Z. Liang, Y. Cui, Improved lithium-sulfur batteries with a conductive coating on the separator to prevent the accumulation of inactive S-related species at the cathode-separator interface, Energy Environ. Sci., 7 (2014) 3381-3390.

[40] R.H. Lara, J.V. Garcia-Meza, R. Cruz, D. Valdez-Perez, I. Gonzalez, Influence of the sulfur species reactivity on biofilm conformation during pyrite colonization by Acidithiobacillus thiooxidans, Appl. Microbiol. Biotechnol., 95 (2012) 799-809. 
[41] J. Liu, Y. Wen, Y. Wang, P.A. van Aken, J. Maier, Y. Yu, Carbon-encapsulated pyrite as stable and earth-abundant high energy cathode material for rechargeable lithium batteries, Adv. Mater., 26 (2014) 6025-6030. 


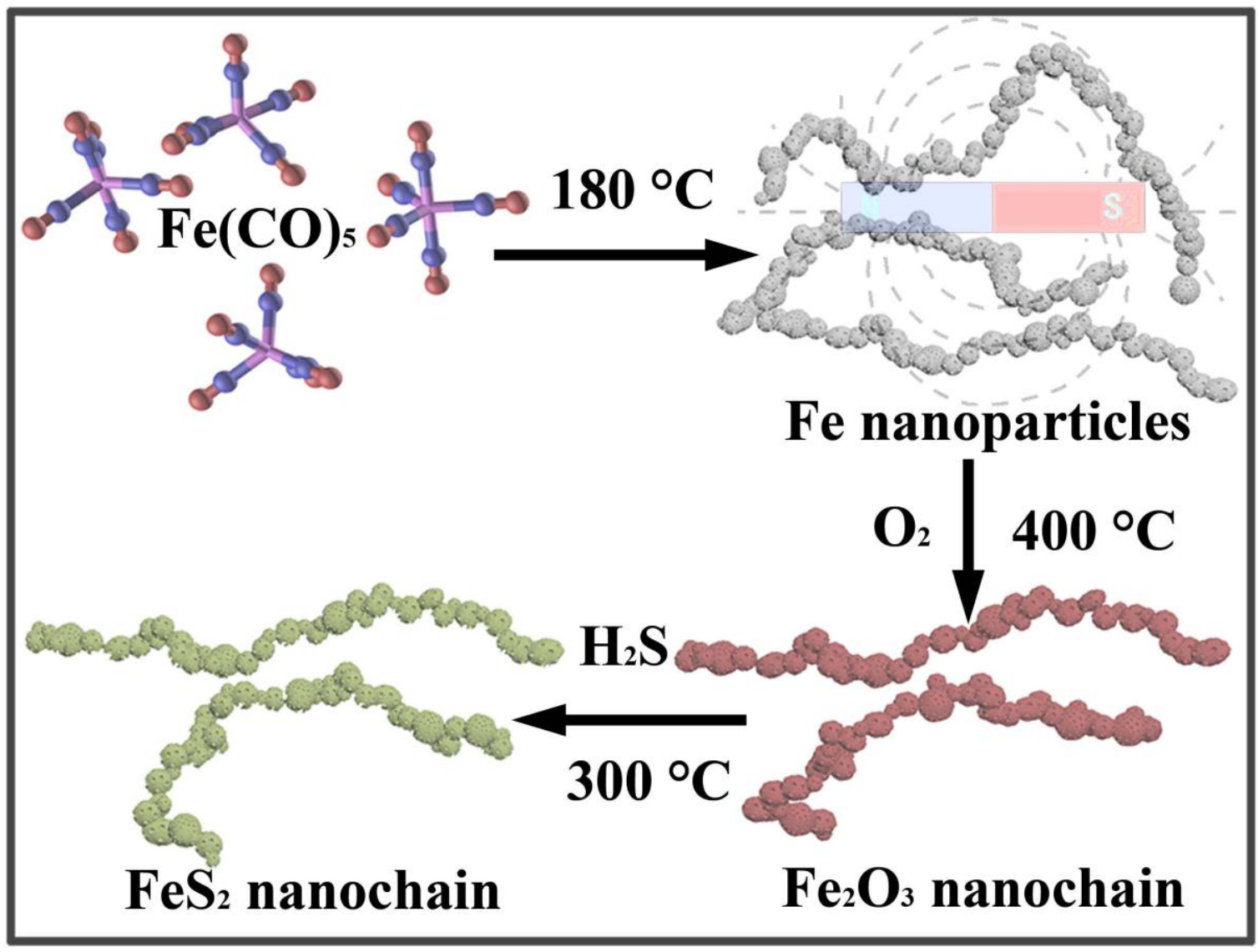

Fig. 1 Schematic diagram of the synthesis process of the $\mathrm{FeS}_{2}$ nanochain network with the assistance of magnetic field. 

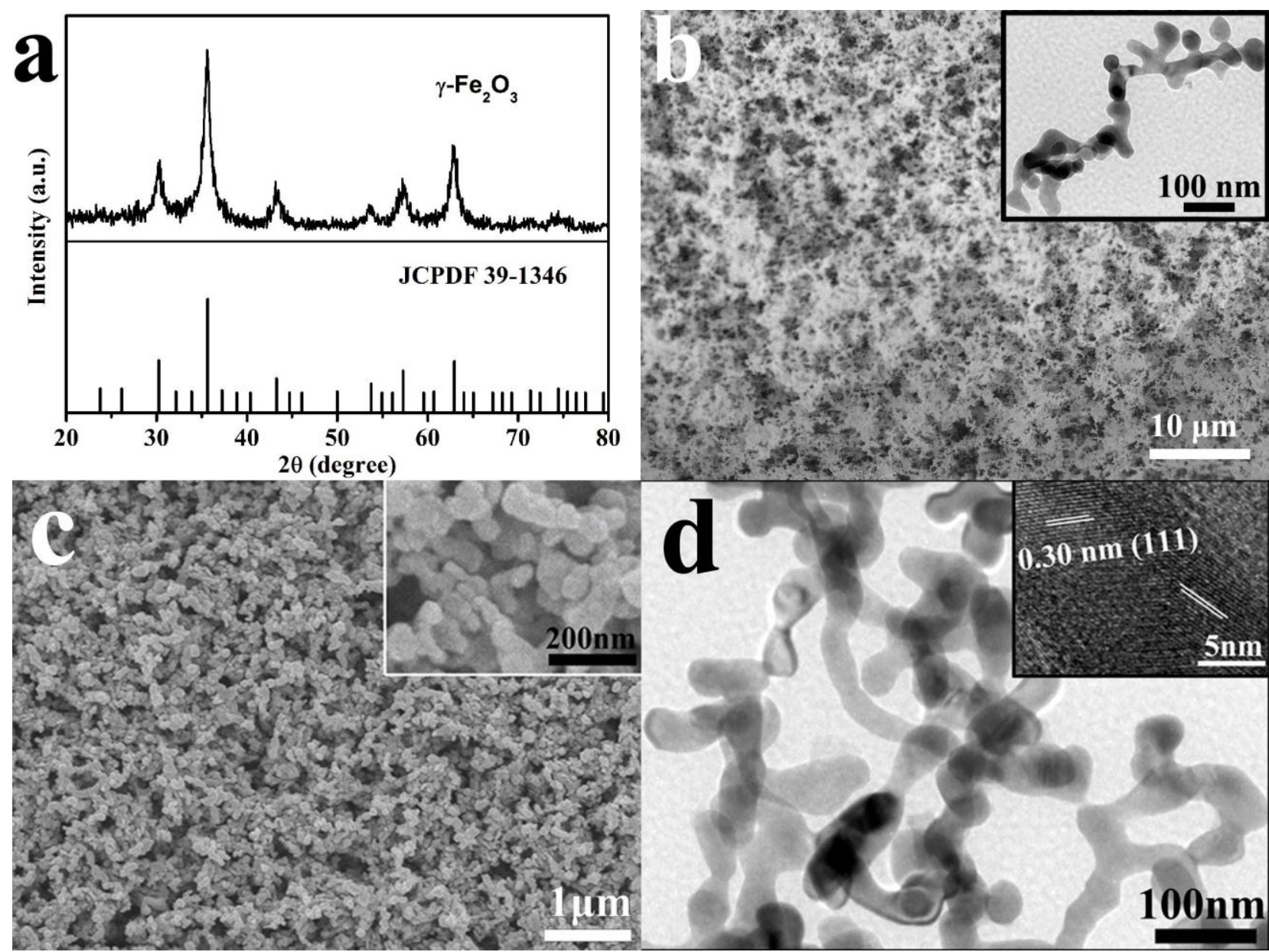

Fig. 2 (a) XRD patterns, (b) SEM and TEM (inset) images of the as-prepared $\gamma-\mathrm{Fe}_{2} \mathrm{O}_{3}$ nanochain network; (c) Low-magnification and high-magnification (inset) SEM images of the as-prepared $\mathrm{FeS}_{2}$ nanochain network; (d) TEM and HRTEM (inset) images of the as-prepared $\mathrm{FeS}_{2}$ nanochain assembly. 

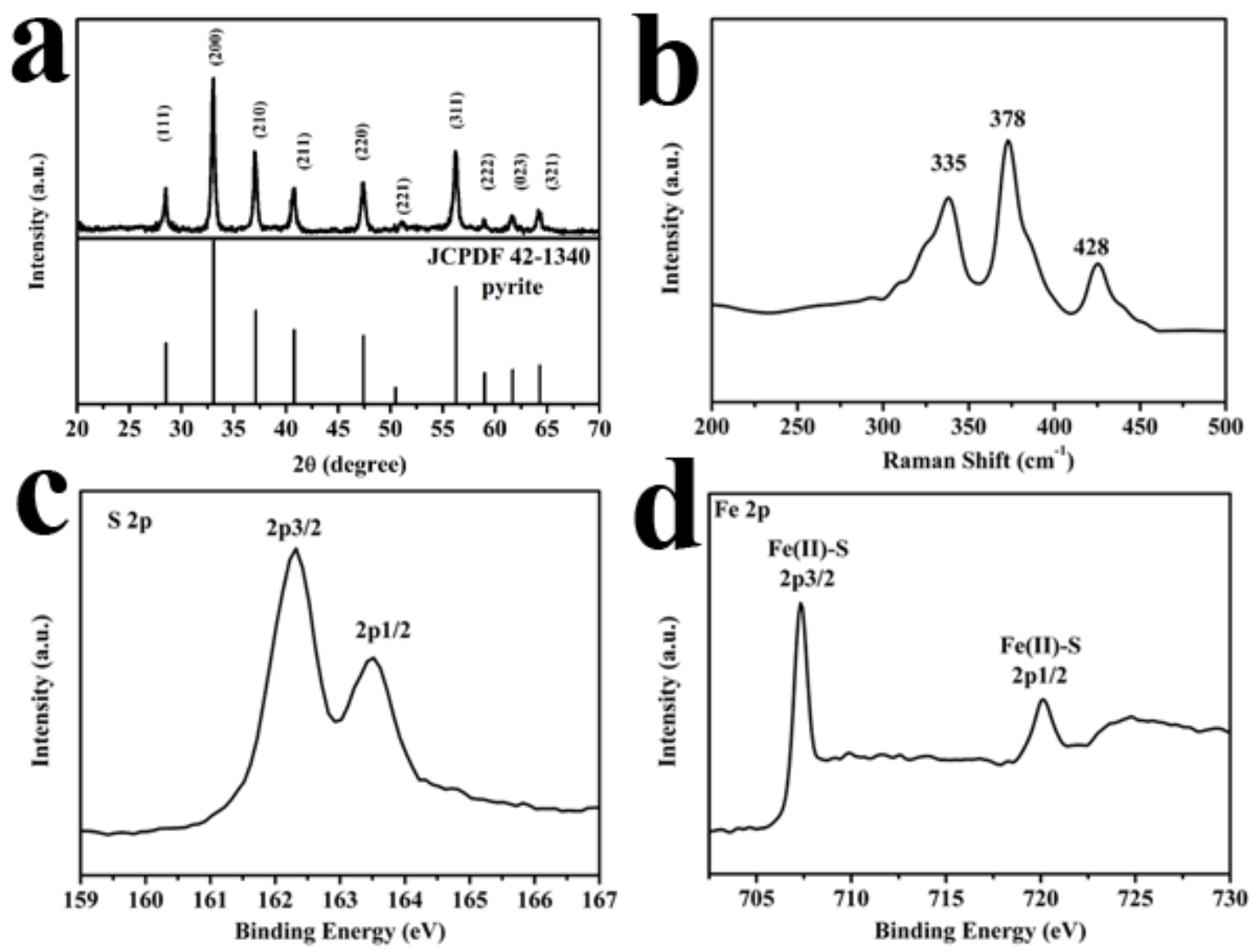

Fig. 3 (a) XRD patterns, (b) Raman spectrum, (c) S core level and (d) high resolution Fe XPS spectra of $\mathrm{FeS}_{2}$ nanochain. 

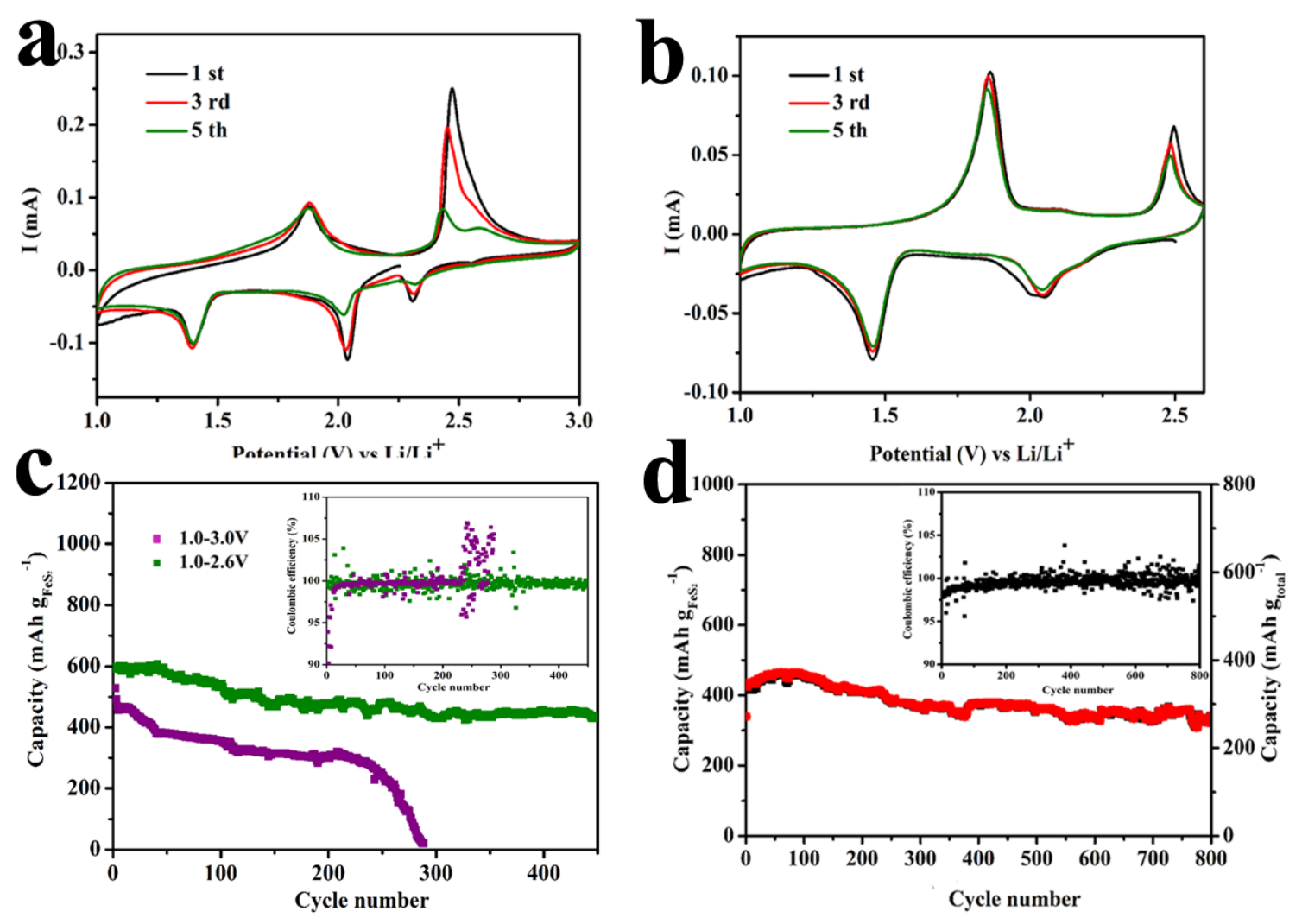

Fig. 4 Cyclic voltammograms of the $\mathrm{FeS}_{2}$ nanochain samples for the first, third and fifth cycles at $0.5 \mathrm{mV} \mathrm{s}^{-1}$ in the voltage range of (a) $1.0-3.0 \mathrm{~V}$ vs. $\mathrm{Li} / \mathrm{Li}^{+}$, (b) $1.0-2.6 \mathrm{~V}$ vs. $\mathrm{Li} / \mathrm{Li}^{+}$. Cycling performance tests of $\mathrm{FeS}_{2}$ nanochain under (c) 1.0-2.6 V and 1.0-3.0 V at $0.2 \mathrm{C}$. (d) $1.0-2.6 \mathrm{~V}$ at 0.5 C. Insets are their corresponding coulombic efficiencies. 

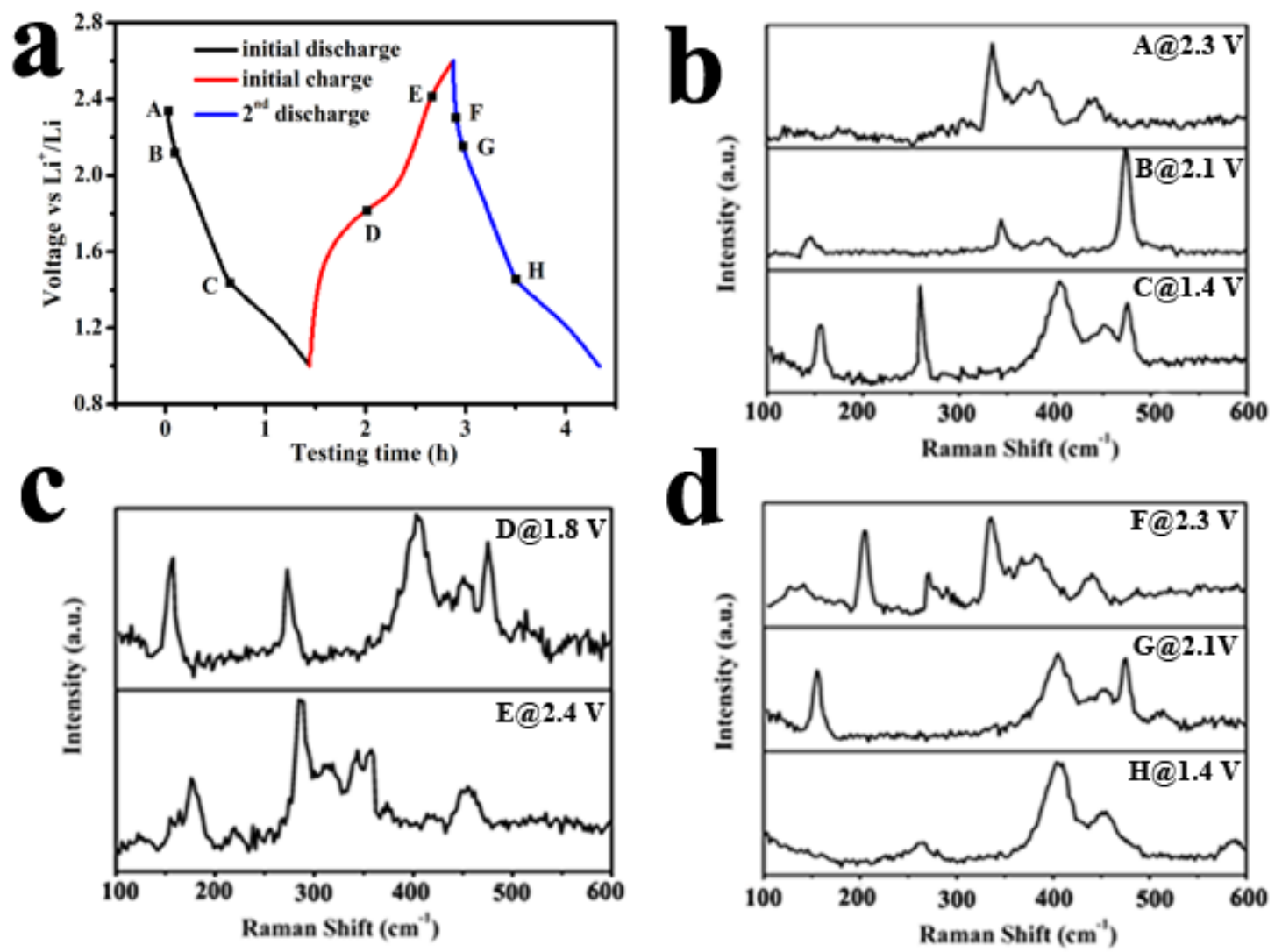

Fig. 5 (a) Discharge/charge voltage profile of the $\mathrm{FeS}_{2}$. Typical Raman spectrum of the electrode under specific voltages during (b) initial discharging process, (c) initial charging process, (d) $2^{\text {nd }}$ discharging process. 